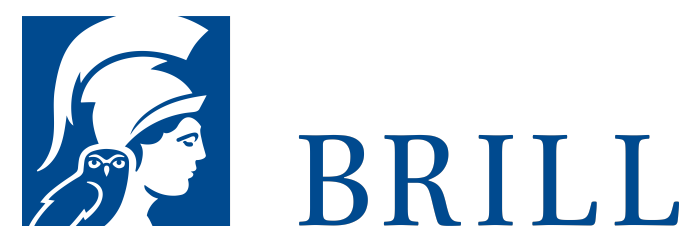

\title{
Die Geschichte der abendländischen Lebensformen
}

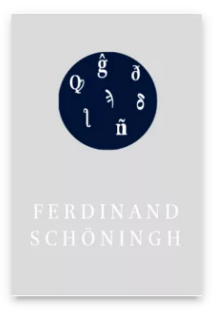

Published: 11

Sep 1990

Pages: 396

Seiten

Subjects:

General,

Education

Publisher: Brill |

Schöningh

Series:

Wilhelm Flitner, Gesammelte Schriften,

Volume: 7

Paperback

ISBN: $978-3^{-}$ 506-72567-7

Price:

[US] \$116.0o 
Please send your order to: Brockhaus/Commission Tel: +49(o)71 541327 9216 | E-Mail: brill@ $\underline{\text { brocom.de }}$

For questions please contact: Brill Deutschland GmbH

Wollmarktstraße 115 | 33098 Paderborn | Germany

Tel: +49 (o)5251 69975 o | E-Mail: sales@brill.com. 